\title{
Epilepsia Partialis Continua in a Patient with Progressive Multiple Sclerosis
}

\author{
Progresif Multipl Sklerozlu Hastada Epilepsiya Parsiyalis Kontinua
}

\author{
(D) Gökhan Görken ${ }^{1}$, (D) Abdullah Yılgör ${ }^{2}$ \\ ${ }^{1}$ Mus Bulanik State Hospital, Clinic of Neurology, Mus, Turkey \\ 2Van Yuzuncu Yil University Faculty of Medicine, Department of Neurology, Van, Turkey
}

\begin{abstract}

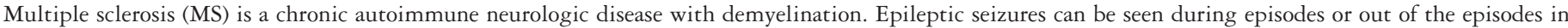

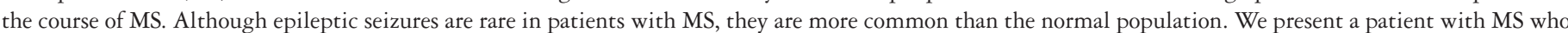

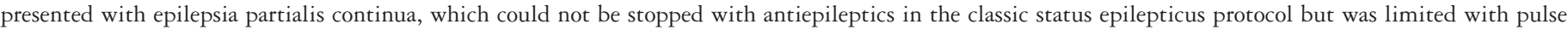
steroid therapy.
\end{abstract}

Keywords: MS, EPC, epilepsia partialis continua, steroid, epilepsy, partialis, spell, multiple sclerosis

\section{$\ddot{O} z$}

Multipl skleroz (MS), demiyelinizasyon ile seyreden, otoimmün, kronik nörolojik bir hastalıktır. MS hastalı̆̆ının seyrinde atak ya da atak dışı dönemlerde epileptik nöbetler görülebilmektedir. Epileptik nöbetler MS'li hastalarda seyrek görülse de normal popülasyona göre fazladır. Biz klasik status epileptikus protokolündeki anti-epileptiklerle durdurulamayan ancak pulse steroid tedavisiyle sınırlandırılabilen epilepsiya parsiyalis kontinua ile prezente olan bir MS'li hastamızı sunuyoruz.

Anahtar Kelimeler: MS, EPC, epilepsia parsiyalis kontinua, steroid, epilepsi, parsiyalis, nöbet, multipl skleroz

\section{Introduction}

The incidence of epileptic seizures in multiple sclerosis (MS) patients is higher than the normal population. These seizures, which are seen during or outside an attack, may present as generalized and focal seizures. In MS patients, seizures, which can sometimes be limited by the initial status epilepticus treatment, can sometimes be presented with advanced status therapies. In this case report, we present an MS patient whose seizure presented as epilepsy partialis continua and limited to pulse steroid therapy.

\section{Case Report}

A 28-year-old female patient, who had been followed up for 12 years for MS, was still being followed up with a diagnosis of progressive MS, presented to our emergency department with symptoms of change in consciousness and jerks on the left side of her face for two days. The general condition of the patient, who was already bedridden, was poor due to the decrease in oral intake. She was somnolent, he could move her four extremities minimally, her deep tendon reflexes were globally hyperactive, and contractions were present in the left side of her face. Except for diffuse demyelinating plaques, no active contrast enhancement was observed in magnetic resonance imaging (MRI) (Figure 1). The patient, whose temperature was found to be normal in the emergency department, and in whom no significant pathology was found in the cerebrospinal fluid examination and routine blood tests, was admitted to our intensive care unit (ICU).

During the video electroencephalogram (EEG) monitorization, intravenous (IV) diazepam at a dose of $10 \mathrm{mg}$ was administered to the patient who had epileptiform discharges characterized by spikes and sharp waves in almost all of the recording in the right hemisphere. Although the frequency of paroxysmal epileptiform discharges and jerks on the left side of her face decreased partially,

Address for Correspondence/Yazışma Adresi: Gökhan Görken MD, Mus Bulanik State Hospital, Clinic of Neurology, Mus, Turkey Phone: +90 5348579255 E-mail: doktorazad@gmail.com ORCID: orcid.org/0000-0001-9197-8298

Received/Geliş Tarihi/ 30.11.2019 Accepted/Kabul Tarih: 01.11.2020

(T) Telif Hakk1 2021 Türk Nöroloji Derneği

Türk Nöroloji Dergisi, Galenos Yayınevi tarafından basılmıştır. 
they recurred later. In our ICU, $1.500 \mathrm{mg}$ IV phenytoin and 2.200 mg IV valproic acid (VPA) were loaded, respectively, and the frequency of jerks on her face continued, although their frequency decreased. It was observed that the activity, characterized by spikesharp waves, continued in the right hemisphere of the patient, who underwent video EEG monitorization again (Figure 2). It could not be decided whether the patient's seizure was related to an MS attack, it was thought that there was a seizure due to immune mechanisms, and IV $1.000 \mathrm{mg}$ pulse steroid therapy was initiated. EEG examination performed 12 hours after the first dose showed a decrease in the frequency and amplitude of epileptiform activity, which was characterized by repetitive spike-sharp waves. The patient, whose jerks on her face significantly decreased, was followed up in the ICU without being intubated. The seizures of the patient ceased completely on the $3^{\text {rd }}$ day of the pulse steroid therapy and the rhythmic paroxysms in her EEG disappeared. Later, levetiracetam (LEV) was added to the treatment and the seizures did not recur.

\section{Discussion}

It has been reported that the incidence of epileptic seizures increases in patients with MS $(1,2)$, which increases mortality $(3,4,5,6,7)$. Although its pathogenesis has not been clarified, it is thought that hypersynchronization in the brain caused by cortical and subcortical lesions causes seizures in patients, and the mechanism by which these lesions become epileptogenic is
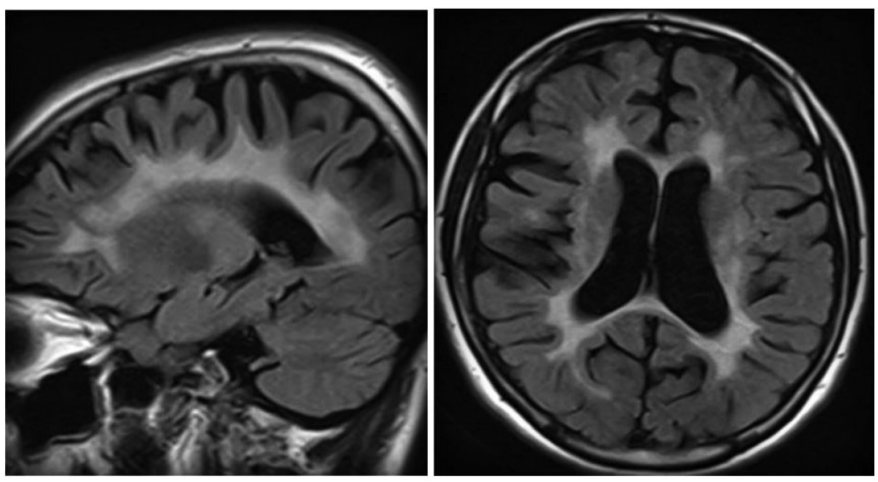

Figure 1. Diffuse demyelinating plaques without contrast enhancement are seen in the patient's brain MRI-T2 sequences

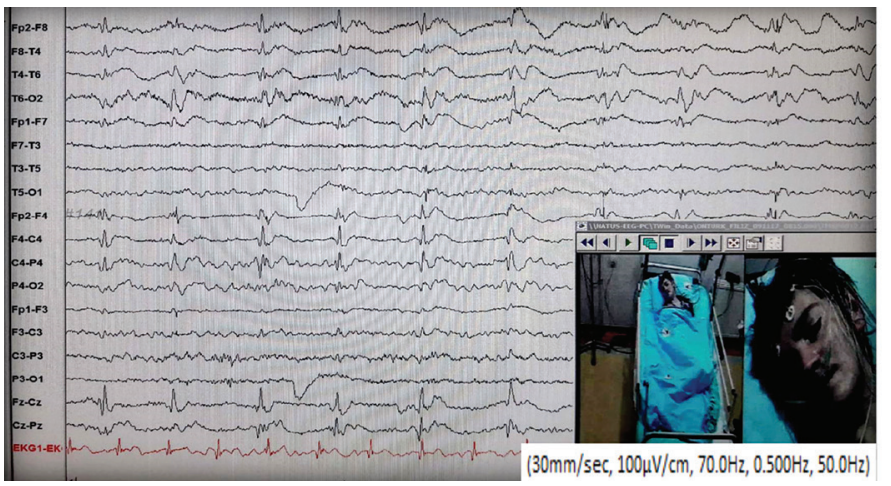

Figure 2. Despite antiepileptic drugs, epileptiform discharges characterized by spikes and sharp waves observed in almost all of the electroencephalogram recording in the right hemisphere unknown $(7,8,9)$. Although it is thought that epileptic seizures are mostly seen during an attack, they can occur at any time other than an attack, as in our patient (10).

In epileptic seizures, especially in refractory status epilepticus due to autoimmune etiologies, and in epileptic seizures where immunity and inflammation are thought to play a role, it has been observed that antiepileptic drugs are not effective and immune therapy is successful (11). Steroids, IV immunoglobulin, plasmapheresis, and azathioprine are used in immune therapy in these patients, and recently cyclophosphamide and monoclonal antibodies such as rituximab, efalizumab, and natalizumab have been reported to be used (11). Epileptic seizures can occur with all kinds of systemic autoimmune diseases. It is thought that the pathogenesis of these seizures may involve direct central nervous system involvement, a decrease in the seizure threshold or antineuronal antibodies (12).

There is an ongoing debate about the prognosis of seizures in MS and whether anticonvulsive therapy should be initiated after a single seizure. Typically, in patients without additional neurologic comorbidity, anticonvulsive therapy may not be initiated after a single seizure if EEG and MRI do not demonstrate high evidence of seizure recurrence risk $(13,14)$. It is thought that the first seizure in patients with MS should be considered as an acute symptomatic seizure, as in other brain pathologies, and we should be more selective in starting medication (15). However, it is stated that seizure relapse is frequent in patients with MS presenting with status epilepticus and anticonvulsive therapy is recommended (14).

Some studies have reported that patients with progressive MS have a higher risk of seizure recurrence $(16,17)$. There are also studies showing that the risk of epileptic seizures increases with disease progression $(18,19)$. In general, seizures in patients with progressive MS are thought to be resistant to treatment, and it is thought that seizures provoked during an attack are easy to control (10). Anti-epileptic prophylaxis treatment is required in patients after focal or generalized status epilepticus. Low doses of VPA, LEV, and other new antiepileptic drugs may be preferred because they have little effect on motor or cognitive functions (13).

As a result, all kinds of seizures can be observed in patients with MS, and even MS can present with seizures first. It should be kept in mind that these seizures may be seen during an attack and autoimmune epileptic seizures not related to attack may also occur. Although epilepsia partialis continua is rarely seen in patients with MS, it is resistant to antiepileptic treatments as in our patient, and it can give a dramatic response to pulse steroid therapy, which is beneficial in MS attacks, and immune therapy for autoimmune epileptic seizures. Considering this common benefit, early initiation of pulse steroid therapy in patients with MS presenting with seizures may lead to good clinical outcomes (11).

Ethics

Informed Consent: Consent form was filled out by all participants.

Peer-review: Externally peer-reviewed.

\section{Authorship Contributions}

Surgical and Medical Practices: G.G., Concept: G.G., Design: G.G., Data Collection or Processing: G.G., Analysis or Interpretation: A.Y., Literature Search: G.G., Writing: G.G. 
Conflict of Interest: No conflict of interest was declared by the authors.

Financial Disclosure: The authors declared that this study received no financial support.

\section{References}

1. Poser CM, Brinar VV. Epilepsy and multiple sclerosis. Epilepsy Behav 2003;4:6-12.

2. Nicoletti A, Sofia V, Biondi R, et al. Epilepsy and multiple sclerosis in Sicily: a population-based study. Epilepsia 2003;44:1445-1448.

3. Alusi SH, Worthington J, Glickman S, Bain PG. A study of tremor in multiple sclerosis. Brain 2001;124:720-730.

4. Pittock SJ, McClelland RL, Mayr WT, Rodriguez M, Matsumoto JY. Prevalence of tremor in multiple sclerosis and associated disability in the Olmsted County population. Mov Disord 2004;9:1482-1485.

5. Rinker JR, Salter AR, Walker H, et al. Prevalence and characteristics of tremor in the NARCOMS multiple sclerosis registry: a cross-sectional survey. BMJ Open 2015;5:e006714.

6. Allen AN, Seminog OO, Goldcare MJ. Association between multiple sclerosis and epilepsy: large population-based record-linkage studies. BMC Neurol 2013,13:189.

7. Chou I, Kuo CF, Tanasescu R, et al. Epilepsy and associated mortality in patients with multiple sclerosis. Eur J Neurol 2019;26: 342-e23.

8. Lucchinetti CF, Popescu BFG, Bunyan RF, et al. Inflammatory cortical demyelination in early multiple sclerosis. N Engl Med J 2011;365:21882197.
9. Kutzelnigg A, Lucchinetti CF, Stadelmann C, et al. Cortical demyelination and diffuse white matter injury in multiple sclerosis. Brain 2005;128:27052712.

10. Atmaca MM, Gürses C. Status epilepticus and multiple sclerosis: a case presentation and literature review. Clin EEG Neurosci 2018;49:328-334.

11. Melvin JJ, Hardison HH. Immunomodulatory treatments in epilepsy. Semin Pediatr Neurol 2014;21:232-237

12. Kürtüncü M, Altunrende B, Akman Demir G. Epilepsi ile ilişkili sistemik otoimmün hastalıklar. Epilepsi 2016;22(Suppl 1):58-66.

13. Bell GS, Neligan A. Outcome of seizures in the general population after 25 years: a prospective follow-up, observational cohort study. J Neurol Neurosurg Psychiatry 2016;87:843-850.

14. Langenbruch L, Krämer J, Güler S, et al. Seizures and epilepsy in multiple sclerosis: epidemiology and prognosis in a large tertiary referral center. J Neurol 2019;266:1789-1795.

15. Spatt J, Chaix R, Mamoli B. Epileptic and non-epileptic seizures in multiple sclerosis. J Neurol 2001;248:2-9.

16. Mahamud Z, Burman J, Zelano J. Risk of epilepsy after a single seizure in multiple sclerosis. Eur J Neurol 2018;25:854-860.

17. Sponsler JL, Kendrick-Adey AC. Seizures as a manifestation of multiple sclerosis.0 Epileptic Disord 2011;13:401-410.

18. Chou IJ, Kuo CF, Tanasescu R, et al. Epilepsy and associated mortality in patients with multiple sclerosis. Eur J Neurol. 2019;26:342-e23.

19. Gasparini S, Ferlazzo E, Ascoli M, et al. Risk factors for unprovoked epileptic seizures in multiple sclerosis: a systematic review and meta-analysis. Neurol Sci 2017:38:399-406 